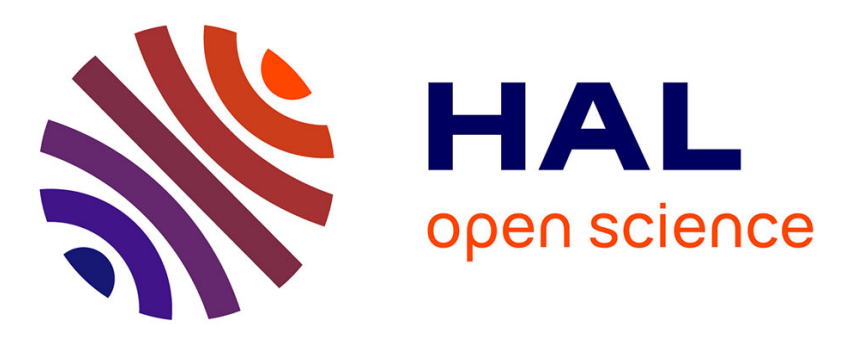

\title{
The 1979-2005 Greenland ice sheet melt extent from passive microwave data using an improved version of the melt retrieval XPGR algorithm
}

Xavier Fettweis, Jean-Pascal van Ypersele, Hubert Gallée, Filip Lefebre, W. Lefebvre

\section{To cite this version:}

Xavier Fettweis, Jean-Pascal van Ypersele, Hubert Gallée, Filip Lefebre, W. Lefebvre. The 19792005 Greenland ice sheet melt extent from passive microwave data using an improved version of the melt retrieval XPGR algorithm. Geophysical Research Letters, 2007, 34 (L05502), 1 à 5 p. 10.1029/2006GL028787 . insu-00376275

\section{HAL Id: insu-00376275 \\ https://hal-insu.archives-ouvertes.fr/insu-00376275}

Submitted on 11 Mar 2021

HAL is a multi-disciplinary open access archive for the deposit and dissemination of scientific research documents, whether they are published or not. The documents may come from teaching and research institutions in France or abroad, or from public or private research centers.
L'archive ouverte pluridisciplinaire HAL, est destinée au dépôt et à la diffusion de documents scientifiques de niveau recherche, publiés ou non, émanant des établissements d'enseignement et de recherche français ou étrangers, des laboratoires publics ou privés. 


\title{
The 1979-2005 Greenland ice sheet melt extent from passive microwave data using an improved version of the melt retrieval XPGR algorithm
}

\author{
X. Fettweis, ${ }^{1}$ J.-P. van Ypersele, ${ }^{1}$ H. Gallée, ${ }^{2}$ F. Lefebre, ${ }^{3}$ and W. Lefebvre ${ }^{1}$ \\ Received 15 November 2006; revised 13 January 2007; accepted 1 February 2007; published 14 March 2007.
}

[1] Analysis of passive microwave satellite observations over the Greenland ice sheet reveals a significant increase in surface melt over the period 1979-2005. Since 1979, the total melt area was found to have increased by $+1.22 \times$ $10^{7} \mathrm{~km}^{2}$. An improved version of the cross-polarized gradient ratio (XPGR) technique is used to identify the melt from the brightness temperatures. The improvements in the melt retrieval XPGR algorithm as well as the surface melt acceleration are discussed with results from a coupled atmosphere-snow regional climate model. From 1979 to 2005 , the ablation period has been increasing everywhere over the melt zone except in the regions where the model simulates an increased summer snowfall. Indeed, more snowfall in summer decreases the liquid water content of the snowpack, raises the albedo and therefore reduces the melt. Finally, the observed melt acceleration over the Greenland ice sheet is highly correlated with both Greenland and global warming suggesting a continuing surface melt increase in the future. Citation: Fettweis, X., J.-P. van Ypersele, H. Gallée, F. Lefebre, and W. Lefebvre (2007), The 1979-2005 Greenland ice sheet melt extent from passive microwave data using an improved version of the melt retrieval XPGR algorithm, Geophys. Res. Lett., 34, L05502, doi:10.1029/ 2006 GL028787.

\section{Introduction}

[2] The melting of the Greenland ice sheet has an effect on the stability of the Thermohaline Circulation (THC) and the global sea level rise. On the one hand, increases in the freshwater flux from the Greenland ice sheet (from glacier discharge and meltwater run-off) could perturb the THC by reducing the density contrast driving it. On the other hand, the melting of the whole Greenland ice sheet would account for a global mean sea level rise of $7.4 \mathrm{~m}$ [Bamber et al., 2001]. A warmer climate, as observed these last years, suggests a growth in thickness inland due to higher precipitation caused by greater oceanic evaporation and a perifical ice sheet thinning due to increasing surface melt [Intergovernmental Panel on Climate Change, 2001]. These trends are confirmed by recent altimetry observations which show indeed a thinning of the Greenland ice sheet margins caused

${ }^{1}$ Institut d'Astronomie et de Géophysique Georges Lemaître, Université Catholique de Louvain, Louvain-la-Neuve, Belgium.

${ }^{2}$ UMR 5183, Laboratoire de Glaciologie et Géophysique de l'Environnement, CNRS, Université Joseph Fourier, Saint-Martin dH'ères, France.

${ }^{3}$ Integrated Environmental Studies, Flemish Institute for Technological Research, Mol, Belgium.

Copyright 2007 by the American Geophysical Union. 0094-8276/07/2006GL028787 by both enhanced meltwater runoff and enhanced glacier flow and, a growth at higher elevation [Krabill et al., 2004; Johannessen et al., 2005; Rignot and Kanagaratnam, 2006]. According to Zwally et al. [2002], one of the explanations for the observed Greenland glaciers acceleration could be related to the enhanced surface meltwater production penetrating to the bed to lubricate its motion. The altimetry observations of these last years rather suggest a small mass gain of the whole Greenland ice sheet [Zwally et al., 2005], while this trend is not unanimous [Krabill et al., 2004] as show by very recent gravity measurements from the Gravity Recovery and Climate Experiment (GRACE) [Chen et al., 2006; Velicogna and Wahr, 2006; Luthcke et al., 2006]. However, most of these observation based studies are based on data from too short periods to find significant trends and continued monitoring is needed to identify any future change in the Greenland ice sheet mass balance.

[3] Satellites monitor the surface melt on the Greenland ice sheet since almost thirty years in the microwave wavelength range. This allows to identify changes at the surface of the ice sheet, on a statistically significant period without directly evaluating the ice sheet mass balance. These data have already been used to show an increase of the surface melt on Greenland but no statistically significant positive melt trend has been found until now [Abdalati and Steffen, 2001; Fettweis et al., 2006]. In this study, we extend the analysis of the previous works over the period 1979-2005 to confirm the significant enhanced surface melt detected by the passive microwave satellite data. The melt extent is retrieved from the microwave brightness temperatures via an improved version of the cross-polarized gradient ratio (XPGR) technique [Abdalati and Steffen, 1997] to reduce the perturbation due to the atmospheric variability [Fettweis et al., 2006]. Finally, the trends found in the microwave data will be discussed by using results from the regional climate model MAR (Modèle atmosphérique régional).

\section{MAR Model}

[4] As in the work by Fettweis et al. [2006], we use results from the MAR model coupled to the Soil Ice Snow Vegetation Atmosphere Transfer (SISVAT) scheme to discuss the melt extent variability derived from the passive microwave satellite data. The atmospheric part of MAR is fully described by Gallée and Schayes [1994], while the SISVAT scheme is detailed by De Ridder and Gallée [1998] and by Gallée et al. [2001]. The simulation starts in September 1978 and lasts until December 2005 with a spatial resolution of $25 \mathrm{~km}$. The ERA-40 reanalysis (1977-2002) and after that, the operational analysis 


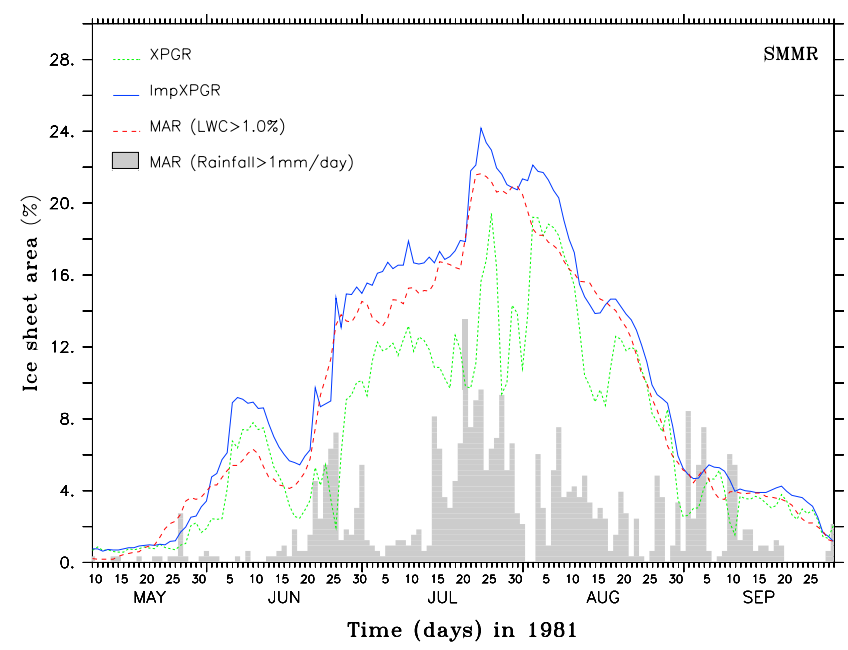

Figure 1. Comparison between the MAR simulation (dashed line) and the SMMR satellite-derived observations using XPGR (dotted line) and ImpXPGR technique (solid line) of the daily averaged melt extent zone in 1981. Melt is expressed in percentage of the Greenland ice sheet area. According to Abdalati and Steffen [1997], we use a mean Liquid Water Content (LWC) of $1 \%$ by volume in the top metre of snow as a threshold value to distinguish melt from non-melt points in the MAR simulation. Also shown is the percentage of Greenland ice sheet area where MAR simulates daily rainfall greater than $1 \mathrm{~mm} /$ day (grey bars).

(2002-2005) from the European Centre for Medium-Range Weather Forecasts (ECMWF) are used to initialize the meteorological fields at the beginning of the simulation and to force the lateral boundaries every 6 hours with temperature, specific humidity and wind components which are interpolated in time. The schemes and the set-up used here are fully described by Fettweis et al. [2005].

\section{Passive Microwave Satellite Observations}

[5] The passive brightness temperatures used to monitor the melt extent come from the Scanning Multichannel Microwave Radiometer (SMMR) [1979-1987] and Special Sensor Microwave/Imager (SSM/I) [1987-2005] instruments providing daily near-continuous coverage since 1979. These data, arranged on a regular grid of $25 \mathrm{~km} \times$ $25 \mathrm{~km}$ are provided by the National Snow and Ice Data Center (NSIDC, Boulder, Colorado) [Armstrong et al., 1994; Knowles et al., 2002]. The melt extent over the ice sheet is deduced from the microwave signal by using the XPGR technique of Abdalati and Steffen [1997, 2001] with the four improvements made by Fettweis et al. [2006] to reduce the perturbations in the remote melt signal due to the atmospheric variability. The original XPGR melt retrieval algorithm from Abdalati and Steffen [1997] together with the four improvements described by Fettweis et al. [2006] will be denoted hereafter ImpXPGR. The XPGR technique compares a normalized difference between the $19-\mathrm{GHz}$ horizontal polarized brightness temperature $(\mathrm{T} 19 \mathrm{H})$ and the $37-\mathrm{GHz}$ vertical polarized brightness temperature (T37V) with a threshold value to distinguish melt from non-melt points. The threshold values were determined by comparison with the Liquid Water Content (LWC) of the snow pack at ETH-Camp (Greenland) in 1990, 1991, 1992 and 1994, and by intercalibration between the different satellite data sets. The same threshold values as the ones determined by Abdalati and Steffen [2001] are used here with the (Imp)XPGR algorithm. The main improvements in the ImpXPGR algorithm compared to the XPGR algorithm is to impose the continuity of the melt season to remove abnormal gaps shorter than three days between two melting days. The gaps are in general found to be associated with dense clouds mostly causing liquid precipitation on the ice sheet. See Fettweis et al. [2006] for more details about ImpXPGR.

[6] The ImpXPGR technique was originally applied by Fettweis et al. [2006] to the SSM/I data to correct the abnormal low satellite derived melt signal during rainfall events in comparison with in-situ measurements and MAR results. Figure 1 shows that these improvements can also be applied to the SMMR data. As with SSM/I data, important rainfall events at the end of June, the second half of July and at the beginning of September in 1981 perturb the melt signal detected by XPGR. These abnormal melt signals are corrected in ImpXPGR melt fields and match better with the MAR model. The comparison with the MAR model is identical for other years of the SMMR data set. In Figure 1, the Root Mean Square Error (RMSE) between MAR and XPGR (resp. ImpXPGR) melt extent is 4.2 (resp. 1.6) in percent of the ice sheet area.

\section{Results and Discussion}

[7] Over the periode 1979-2005, the cumulated melt extent retrieved by XPGR and ImpXPGR respectively shows an increase of $+0.019 \times 10^{7} \mathrm{~km}^{2}$ year $^{-1}$ and $+0.047 \times 10^{7} \mathrm{~km}^{2}$ year $^{-1}$ (See Figure 2a). From 1979, the total increase in 2005 is respectively $+0.48 \times 10^{7} \mathrm{~km}^{2}$ (i.e. $+28 \%$ ) and $+1.22 \times 10^{7} \mathrm{~km}^{2}$ (i.e. $+54 \%$ ) with a significance of $92.0 \%$ and $99.5 \%$. Following Fettweis et al. [2006], the total surface meltwater runoff of the Greenland ice sheet also significantly increased since 1979. The significance has been tested using a Monte-Carlo method with $1,000,000$ simulations of autocorrelated data series with the same autocorrelation as the (Imp)XPGR time series. The MAR model simulates the same trend as ImpXPGR. The surface melt acceleration is higher using ImpXPGR than using XPGR because rainfall has increased during this period which enhances the probability of perturbations in the microwave melt signal. The ice sheet area on which MAR simulates daily rainfall greater that $1 \mathrm{~mm} /$ day has been extending on average by $+0.006 \times 10^{7} \mathrm{~km}^{2}$ year $^{-1}$ (significance of 98.1\%) since 1979. The trend to heavier rainfall is highly correlated to the warming observed on Greenland as we will see hereafter.

[8] The maximum of both annually cumulated melt area and melt extent occurs in 2005 followed by 2002 in the ImpXPGR melt fields. In the XPGR fields, the maximum annually cumulated melt area occurs in 1991 and the maximum daily melt extent in 2002 according to Steffen et al. [2004] and K. Steffen, Greenland melt extent, 2005, Cooperative Institute for Research in Environmental Sciences, Boulder, Colorado, available at http://cires.colorado. edu/science/groups/steffen/greenland/melt2005/). The trend 

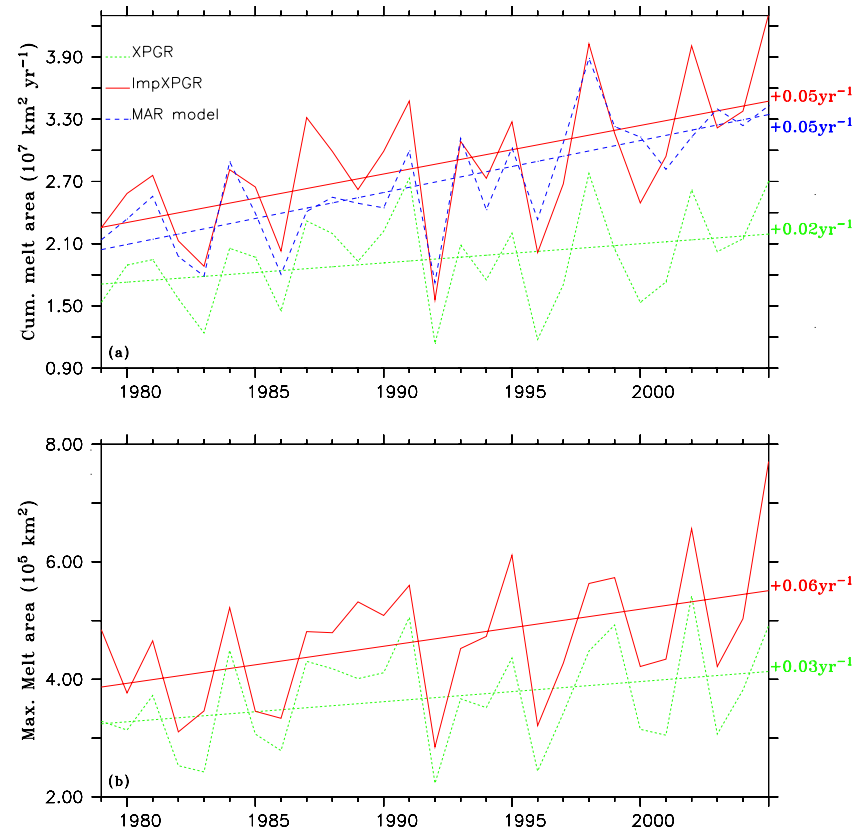

Figure 2. (a) Annually cumulated melt area detected by XPGR (dotted), by ImpXPGR (solid) and simulated by MAR (dashed). (b) Maximum daily melt extent of the ice sheet. The cumulated melt area is defined as the annual total sum of every daily ice sheet melt area and the maximum melt extent is the maximum extent experiencing at least one melt day.

of the maximum extent experiencing at least one melt day shows an increase of $+0.89 \times 10^{5} \mathrm{~km}^{2}$ (i.e. $+28 \%$ ) and $+1.64 \times 10^{5} \mathrm{~km}^{2}$ (i.e. $+42 \%$ ) respectively in XPGR and ImpXPGR since 1979 until now with a significance of 92.9\% and $98.0 \%$ (See Figure $2 b$ ).

[9] This significant snowmelt increase in the microwave satellite data is confirmed in Figure 3 which reveals an increase of the length of the melt season as well as an expansion of the melt area on the Greenland ice sheet throughout the period 1979-2005. The number of melting days increases mainly in the North of Greenland and along the western coast at mid altitude (about near $1500 \mathrm{~m}-$ $2000 \mathrm{~m}$ ). At lower altitude in the western part, no change occurs because the melt period extends already all of the melt season at the beginning of eighties. The changes are smaller along the eastern coast and the trend is even negative in the ImpXPGR fields along the south-eastern mountainous regions of the ice sheet (see Figure 3b). But the microwave brightness temperature could be biased by numerous rock outcrops (boulders) found in this mountainous region [Torinesi et al., 2003]. In the XPGR fields, a decrease of the melt period is recorded along the western margin. Figure $3 \mathrm{c}$ shows an expansion of the largest melt area reaching since the eighties new zones every year (e.g., the South-Dome at an elevation of $2900 \mathrm{~m}$ in 2005 (Steffen, 2005). The expansion of melt area is the most spectacular since the years 2000 in the Northern part of Greenland where no melt has been recorded before above $1500 \mathrm{~m}$.

[10] Since 1979, the MAR model simulates an increase of the mean ice sheet summer temperature of $+2.4^{\circ} \mathrm{C}$ (i.e. $+0.09^{\circ} \mathrm{C}$ by year) in agreement with in situ observations on Greenland [Box, 2002; Chylek et al., 2006]. Figure 4a shows a warming on the whole Greenland ice sheet. This modelled warming is larger at the top of the ice sheet than along the ice sheet margin because the surface temperature of melting snow/ice is limited to $0^{\circ} \mathrm{C}$. The correlation between the average ice sheet summer MAR temperature and the cumulated melt extent retrieved by XPGR and ImpXPGR is respectively 0.66 and 0.77 .

[11] An uniform warming of the ice sheet as shown on Figure 4a would be expected to give an increase of the melt period everywhere on the ice sheet. The negative trends along the south-eastern coast in ImpXPGR fields probably result from heavier snowfall which decreases the liquid water content of the snow pack, raises the albedo and
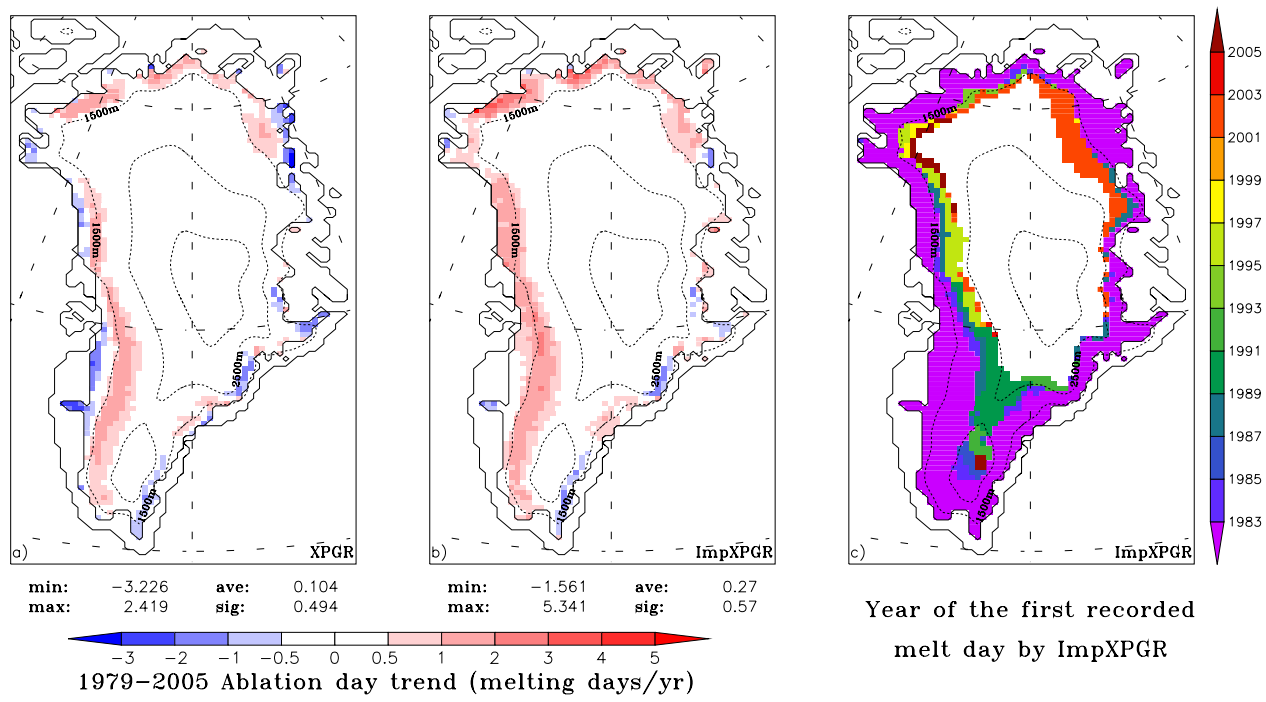

Figure 3. (a) Melt trend (in ablation days $\mathrm{yr}^{-1}$ ) detected by XPGR for the period 1979-2005. (b) Idem by ImpXPGR. (c) Year in which some melt is recorded by ImpXPGR the first time. Negative trends are hatched and surrounded by a black dotted line. Minimum ( $\mathrm{min}$ ) and maximum (max) values are indicated below the figures as well as the ice sheet average (ave) and the standard deviation (sig). 


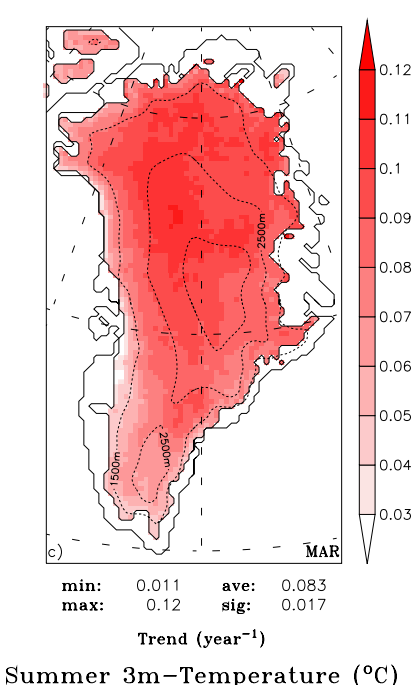

Summer $3 \mathrm{~m}$-Temperature $\left({ }^{\circ} \mathrm{C}\right)$

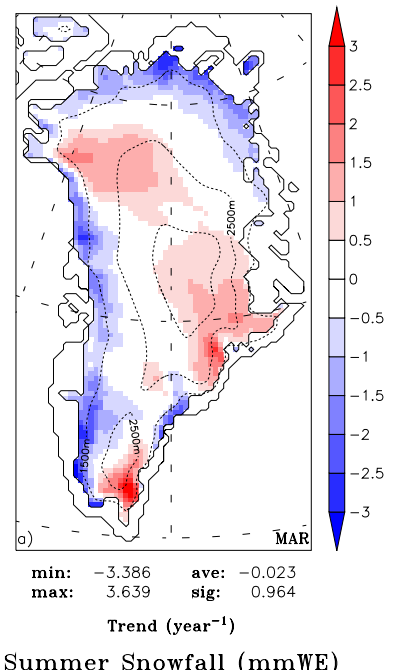

Summer Snowfall (mmWE)

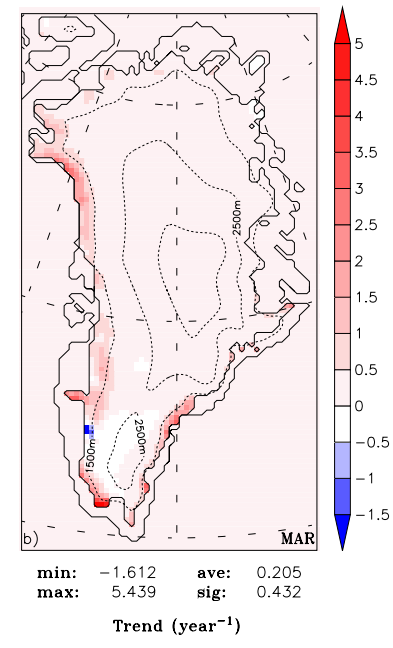

Summer Rainfall (mmWE)

Figure 4. (a) 27-year linear regression change of the $3 \mathrm{~m}$-temperature simulated by MAR in summer (1st may to 30th September). (b) Idem for snowfall. (c) Idem for rainfall. Negative trends are hatched and surrounded by a black dotted line. Minimum ( $\min$ ) and maximum ( $\max$ ) values are indicated below the figures as well as the ice sheet average (ave) and the standard deviation (sig).

therefore reduces the melt. In the other regions of the Greenland ice sheet, MAR simulates rather a decrease of the snowfall in summer (Figure 4b). Part of this snowfall decrease in summer results from the warming, which leads to an increase in the amount of liquid precipitation versus solid precipitation as revealed on Figure 4c. This increase of rainfall in summer which induces enhanced perturbations in the recorded microwave signal explains why XPGR shows a decrease of the ablation period along the western margin because the melt signal is more and more masked by the liquid water in the clouds. In addition, the variability of the melt signal retrieved by XPGR is less in agreement with the global climate variability than ImpXPGR. Indeed, the correlation with the global mean temperature from the Climatic Research Unit (CRU, http://www.cru.uea.ac.uk/ cru/data/) and the annually cumulated melt area is respectively 0.52 and 0.71 .

[12] These results, in agreement with the recent GRACE measurements, suggest that the melt at the surface of the Greenland ice sheet is significantly increasing and will very likely continue to increase in the future following the global warming. This increasing surface melt induced by higher temperatures will have an obvious impact of the Greenland ice sheet mass balance if the precipitation is not increasing in the same proportion and if the melt water-induced ice flow acceleration observed by Zwally et al. [2002] is confirmed in the future.

[13] Acknowledgments. The authors acknowledge the National Snow and Ice Data Center (NSIDC, Boulder, Colorado) for providing the passive microwave satellite data from SMMR and SSM/I (see http://nsidc. org/).

\section{References}

Abdalati, W., and K. Steffen (1997), Snowmelt on the Greenland ice sheet as derived from passive microwave satellite data, J. Clim., 10, 165-175. Abdalati, W., and K. Steffen (2001), Greenland ice sheet melt extent: 1979-1999, J. Geophys. Res., 106, 33,983-33,988.

Armstrong, R. L., K. W. Knowles, M. J. Brodzik, and M. A. Hardman (1994), DMSP SSM/I Pathfinder daily EASE-Grid brightness tempera- tures, July 1987 to December 2005, http://nsidc.org/data/nsidc0032.html, Natl. Snow and Ice Data Cent., Boulder, Colo.

Bamber, J. L., R. L. Layberry, and S. P. Gogineni (2001), A new ice thickness and bed data set for the Greenland ice sheet: 1. Measurement, data reduction, and errors, J. Geophys. Res., 106, 33,773-33,780.

Box, J. E. (2002), Survey of Greenland instrumental temperature records: 1873-2001, Int. J. Climatol., 22, 1829-1847.

Chen, J. L., C. R. Wilson, and B. D. Tapley (2006), Satellite gravity measurements confirm accelerated melting of Greenland ice sheet, Science, 313, 1958-1960, doi:10.1126/science.1129007.

Chylek, P., M. K. Dubey, and G. Lesins (2006), Greenland warming of 1920-1930 and 1995-2005, Geophys. Res. Lett., 33, L11707, doi:10.1029/2006GL026510.

De Ridder, K., and H. Gallée (1998), Land surface-induced regional climate change in southern Israel, J. Appl. Meteorol., 37, 1470-1485.

Fettweis, X., H. Gallée, L. Lefebre, and J.-P. van Ypersele (2005), Greenland surface mass balance simulated by a regional climate model and comparison with satellite derived data in 1990-1991, Clim. Dyn., 24, 623-640, doi:10.1007/s00382-005-0010-y.

Fettweis, X., H. Gallée, L. Lefebre, and J.-P. van Ypersele (2006), The 1988-2003 Greenland ice sheet melt extent by passive microwave satellite data and a regional climate model, Clim. Dyn., 27, 531-541, doi:10.1007/s00382-006-0150-8.

Gallée, H., and G. Schayes (1994), Development of a three-dimensional meso- $\gamma$ primitive equations model, Mon. Weather Rev., 122, 671-685.

Gallée, H., G. Guyomarc'h, and E. Brun (2001), Impact of the snow drift on the Antarctic ice sheet surface mass balance: Possible sensitivity to snowsurface properties, Boundary Layer Meteorol., 99, 1-19.

Intergovernmental Panel on Climate Change (2001), Climate Change 2001: The Scientific Basis. Contribution of Workings Group I to the Third Assessment Report of the Intergovernmental Panel on Climate Change, edited by J. T. Houghton et al., 881 pp., Cambridge Univ. Press, New York.

Johannessen, O. M., K. Khvorostovsky, M. W. Miles, and L. P. Bobylev (2005), Recent ice sheet growth in the interior of Greenland, Sciencexpress, 510, doi:10.1126/science.1115356.

Knowles, K., E. Njoku, R. Armstrong, and M. J. Brodzik (2002), Nimbus-7 SMMR Pathfinder Daily EASE-Grid Brightness Temperatures [CDROM], Natl. Snow and Ice Data Cent., Boulder, Colo.

Krabill, W., et al. (2004), Greenland Ice Sheet: Increased coastal thinning, Geophys. Res. Lett., 31, L24402, doi:10.1029/2004GL021533.

Luthcke, S. B., H. J. Zwally, W. Abdalati, D. D. Rowlands, R. D. Ray, R. S. Nerem, F. G. Lemoine, J. J. McCarthy, and D. S. Chinn (2006), Recent Greenland ice mass loss by drainage system from satellite gravity observations, Science, 314, 1286-1289, doi:10.1126/science.1130776.

Rignot, E., and P. Kanagaratnam (2006), Changes in the velocity structure of the Greenland ice sheet, Science, 311, 986-990, doi:10.1126/ science. 112138 .

Steffen, K., S. V. Nghiem, R. Huff, and G. Neumann (2004), The melt anomaly of 2002 on the Greenland ice sheet from active and passive 
microwave satellite observations, Geophys. Res. Lett., 31, L20402, doi:10.1029/2004GL020444.

Torinesi, O., M. Fily, and C. Genthon (2003), Variability and trends of the summer melt period of Antarctic ice margin since 1980 from microwave sensors, J. Clim., 16, 1047-1060.

Velicogna, I., and J. Wahr (2006), Acceleration of Greenland ice mass loss in spring 2004, Nature, 443, 329-331, doi:10.1038/nature05168.

Zwally, J. H., W. Abdalati, T. Herring, K. Larson, J. Saba, and K. Steffen (2002), Surface melt-induced acceleration of Greenland ice sheet flow, Science, 297, 218-222, doi:10.1126/science.1072708.

Zwally, H. J., M. B. Giovinetto, J. Li, H. G. Cornejo, M. A. Beckley, A. C. Brenner, J. L. Saba, and D. Yi (2005), Mass changes of the Greenland and Antarctic ice sheets and shelves and contributions to sea-level rise: 1992-2002, J. Glaciol., 51(175), 509-527.

X. Fettweis, W. Lefebvre, and J.-P. van Ypersele, Institut d'Astronomie et de Géophysique Georges Lemaître, Université Catholique de Louvain, Chemin du Cyclotron, 2, B-1348 Louvain-la-Neuve, Belgium. (fettweis@) astr.ucl.ac.be)

H. Gallée, UMR 5183, Laboratoire de Glaciologie et Géophysique de l'Environnement, CNRS, UJF, 54, rue Molière, BP 96 F-38402, SaintMartin dH'ères Cedex, France.

F. Lefebre, Integrated Environmental Studies, Flemish Institute for Technological Research, Boeretang 200, B-2400 Mol, Belgium. 